p-ISSN: 1460-4747 e-ISSN: 2655-9412

\title{
PENGARUH PEMBELAJARAN SCIENTIFIC SNOWBALL THROWING TERHADAP MINAT BELAJAR SISWA KELAS 5 SD
}

\section{THE EFFECT OF SCIENTIFIC SNOWBALL THROWING LEARNING ON INTEREST IN LEARNING FOR CLASS 5 SD STUDENTS}

\author{
Silvia Isna Setyaningrum¹, Naniek Sulistya Wardani², Tego Prasetyo ${ }^{3}$ \\ Fakultas Keguruan dan Ilmu Pendidikan, Universitas Kristen Satya Wacana \\ 292015090@student.uksw.edu,wwardani.naniek@gmail.com,tego.prasetyo@uksw.edu
}

\begin{abstract}
ABSTRAK
Tujuan dari penelitian ini adalah untuk mengetahui apakah terdapat pengaruh pembelajaran scientific snowball throwing (S-ST) terhadap minat belajar siswa kelas 5 SD. Jenis penelitian ini adalah penelitian eksperimen dengan desain nonequivalent control group design. Teknik pengambilan sampel adalah purposive stratified quota sampling. Teknik pengumpulan data menggunakan angket dengan instrumen lembar butir pernyataan. Teknik analisis data menggunakan uji t. Kelas eksperimen dan kelas kontrol berdistribusi normal dengan df. 29 dan sig. 0,155>0,05 dan df. 29 dan sig.0,081 >0,05. Kelas eksperimen dan kelas kontrol adalah homogen yang ditunjukkan dengan sig. 0,809 >0,05. Hasil penelitian menunjukkan sig. (2-tailed) $0,029<0,05$, maka terdapat pengaruh yang signifikan pembelajaran S-ST terhadap minat belajar siswa kelas 5 SD. T-hitung 2,241 > 2,009 t-tabel, maka terdapat perbedaan pembelajaran S-ST dan pembelajaran langsung terhadap minat belajar siswa kelas 5 SD.
\end{abstract}

\section{Kata Kunci: Pendekatan Scientific, Model Snowball Throwing, Minat Belajar}

\section{ABSTRACT}

The purpose of this study is to find out whether there is an influence of scientific snowball throwing (S-ST) learning on the learning interest of 5th grade students. This type of research is an experimental study with the design of nonequivalent control group design. The sampling technique was purposive stratified quota sampling. The technique of collecting data uses a questionnaire with the instrument statement sheet. The data analysis technique uses the t test. The experimental class and the control class are normally distributed with df. 29 and sig. 0.619>0.05 and df. 29 and sig.0,328>0.05. The experimental class and control class are homogeneous as indicated by sig. $0.257>0.05$. The results showed sig. (2-tailed) $0.029<0.05$, then there is a significant effect of $S$ ST learning on the learning interest of 5 th grade students. $T$-count 2,241> 2,009 $t$-table, then there are differences in S-ST learning and direct learning on the learning interest of 5th grade students.

\section{Keywords: Scientific Approach, Model Snowball Throwing, Interest in Learning}

\section{PENDAHULUAN}

Pendidikan di Indonesia ini sedang mengalami permasalahan, karena sering berubahnya sistem kurikulum yang berlaku di Indonesia. Indonesia mengalami perubahan kurikulum sebanyak sepuluh kali yaitu Kurikulum 1947 atau disebut Rentjana Pelajaran 1947, Kurikulum 1952, Rentjana Pelajaran Terurai 1952, Kurikulum 1964, Rentjana Pendidikan 1964, Kurikulum 1968, Kurikulum 1975, Kurikulum 1984, Kurikulum 1994 dan Suplemen Kurikulum 1999, Kurikulum 2004, KBK (Kurikulum Berbasis Kompetensi), dan Kurikulum 2013 yang saat ini sedang diterapkan. Oleh karena itu tuntutan terhadap proses pembelajaran yang berkualitas 
semakin tinggi. Menurut Permendikbud No 20 tahun 2016 kurikulum 2013 Standar Kompetensi Lulusan Pendidikan Dasar dan Menengah digunakan sebagai acuan utama pengembangan standar isi, standar proses, standar penilaian pendidikan, standar pendidik dan tenaga kependidikan, standar sarana dan prasarana, standar pengelolaan, dan standar pembiayaan.

Peningkatan kualitas sumber daya manusia melalui bidang pendidikan merupakan salah satu kunci sukses dalam menghadapi era globalisasi. Sehubungan dengan hal itu, pemerintah terus melakukan upaya-upaya demi peningkatan mutu pendidikan di Indonesia. Mulai dari perubahan kurikulum, penataran guru, implementasi model pembelajaran, dan lain sebagainya, namun realita mutu pendidikan Indonesia masih jauh dari yang diharapkan. Pendidikan yang baik akan menjadi acuan tingkat perkembangan suatu bangsa. Tingkat perkembangan suatu bangsa juga ditentukan oleh unsur-unsur kemajuan dan perkembangan suatu pendidikan. Unsurunsur kemajuan pendidikan berupa guru, siswa, sarana dan prasarana pendidikan maupun kebijakan yang telah ditetapkan pemerintah dalam bidang pendidikan. Unsur pendidikan yang sangat berperan penting dalam proses perkembangan pendidikan yaitu guru. Guru merupakan dasar penentu kualitas lulusan siswa yang baik maupun buruk, maka dari itu sangat diperlukan kualitas guru yang profesional dalam proses perkembangan pendidikan. Guru dituntut tidak hanya meguasai materi pelajaran, tetapi juga diharapkan mampu mengelola kelas. Permendikbud No. 22 Tahun 2016 tentang Standar Proses menekankan bahwa pembelajaran tematik terpadu menuntut siswa lebih aktif mengembangkan potensi dirinya, sehingga diperlukan model pembelajaran yang tepat dan sesuai dengan karakteristik siswa. Minat belajar yang tinggi dapat dilihat ketika siswa mengikuti pembelajaran dengan aktif.

Pembelajaran tematik terpadu yang dapat membangkitkan minat belajar yang tinggi, membutuhkan pemilihan pendekatan dan model pembelajaran yang inovatif. Banyak guru yang memilih pembelajaran konvensional. Djamarah (2010 : 97) menjelaskan bahwa, pembelajaran konvensional merupakan sebuah metode belajar tradisional. Dalam hal ini seorang guru melakukan pembelajaran kepada siswa dengan cara ceramah yang diselingi dengan penjelasan mengenai materi yang diberikan serta memberikan latihan soal dan tugas secara monoton. Pembelajaran konvensional merupakan pembelajaran yang lebih berpusat pada guru seperti pembelajaran langsung dan kurang dapat meningkatkan minat belajar siswa yang mengakibatkan 
siswa sulit berperan aktif ketika mengikuti pembelajaran. Dalam pembelajaran langsung guru berperan penuh memberikan materi, sehingga aktifitas siswa tidak menjadi perhatian guru. Kondisi ini tidak nampak minat belajar siswa. Perhatian guru terfokus pada materi.

Dalam kurikulum 2013 menekankan kompetensi siswa yang berbeda dengan penekanan kurikulum sebelumnya. Kurikulum 2006 tujuan pembelajaran menekankan pada materi pembelajaran nampak dibeberapa sekolah masih ada guru yang kurang memperhatikan ketercapaian kompetensi peserta didik. Guru selalu melakukan pembelajaran secara konvensional dan pembelajarannya langsung. Pembelajaran berpusat pada guru dan menjadikan siswa pasif. Siswa tidak bergairah dalam belajar, yang nampak ketika pembelajaran berlangsung adalah belajar siswa secara individu, siswa tidak belajar secara berkelompok. Dalam pembelajaran, siswa tidak menanya tentang materi, siswa hanya menyimak penjelasan dari guru. Siswa tidak tertarik pada pelajaran, siswa hanya mengerjakan sesuai perintah guru. Siswa tidak mempunyai inisiatif belajar, siswa hanya menjawab pertanyaan apabila ditanya. Kondisi itulah yang selalu ada dalam pembelajaran langsung.

Permasalahannya apakah kondisi pembelajaran langsung ini dapat dicoba dengan menggunakan pembelajaran scientific snowball throwing yang disarankan dalam kurikulum 2013. Kurikulum 2013 menekankan pencapaian kompetensi pembelajaran menggunakan scientific dan melibatkan siswa untuk belajar. Keterlibatan siswa akan mendorong minatnya melakukan aktifitas belajar. Cara inilah yang dalam penelitian ini akan dilakukan dalm sebuah eksperimen pembelajaran di kelas.

Permasalahan yang dirumuskan dalam penelitian ini adalah apakah terdapat pengaruh pembelajaran scientific snowball throwing (S-ST) terhadap minat belajar tematik siswa kelas 5 SD.

Pembelajaran S-ST adalah pembelajaran yang menekankan proses penemuan melalui kerja ilmiah yang interaksi pembelajarannya menggunakan snowball. Ada 6 langkah dalam pembelajaran scientific. Menurut M. Hosnan (2014:39), Wijayanti A (2014:104), dan Imas Kurniasi (2014:38) langkah dalam pembelajaran scientific sebagai berikut: 1) Menyimak penjelasan dari guru, 2) Menanya materi pembelajaran yang diterima, 3) Menyoba mengerjakan tugas, 4) Menalar jawaban atas pertanyaan yang diajukan, 5) Membuat kesimpulan, 6) Mengkomunikasikan hasil penemuan. 
Pelaksanaan pembelajaran scientific dapat didesain dengan model snowball throwing. Model ini menurut Ismail (2008:27), Suprijono (2011: 8), dan Saminanto (2010:37) merupakan model pembelajaran yang menggunakan media kertas yang dibentuk seperti gelundungan bola dan menyerupai bola salju. Kertas yang berisi soal dan berbentuk bola dilempar ke teman. Selanjutnya teman membaca soal dan menjawab secara berkelompok. Model pembelajaran snowball throwing, menurut Suprijono (Hizbullah, 2011: 10), Linovia (2015:14), dan Asmani (2011:47) adalah pembelajaran yang menekankan pada interaksi antar siswa atau interaksi siswa dan guru, dengan langkah: 1) Membentuk kelompok masing-masing 5 siswa, 2) ketua kelompok menerima materi, 3) Ketua kelompok sharing materi ke anggota kelompok, 4) Menuliskan pertanyaan dikertas yang disediakan, 5) Kertas yang berisi pertanyaan digelundung menjadi bola, 6) Bola dilempar ke teman, 7) Menyimak jawaban teman yang menerima bola kertas, 8) Menarik kesimpulan jawaban, 9) Evaluasi.

Pembelajaran S-ST dapat didesain dengan langkah-langkah sebagai berikut 1) Membentuk kelompok masing-masing 5 siswa, 2) Menyimak materi, 3) Menulis pertanyaan di kertas yang akan digulung seperti bola, kemudian melempar ke salah satu teman, 4) Mengumpulkan jawaban dari teman secara lisan, 5) Membuat kesimpulan jawaban teman, 6) Mengkomunikasikan hasil temuan.

Pembelajaran S-ST adalah pembelajaran yang melibatkan langsung peserta didik, untuk belajar menemukan sesuatu melalui proses kerja ilmiah dan bermain melempar bola kertas berisi pertanyaan. Dalam proses belajar yang berlangsung dengan melempar bola ke beberapa teman, dan teman menjawab, merupakan aktivitas belajar yang seolah-olah bermain-main. Siswa senang dan tidak tidak terasa kalau aktivitas itu merupakan upaya guru mendorong siswa untuk melakukan aktifitas belajar, sehingga minat belajar siswa dapat dideteksi. Dorongan yang dilakukan guru dan siswa melakukan aktivitas belajar merupakan bentuk minat belajar. Menurut Eveline S dan Hartini N (2014: 176), Mulyasa (2012: 105), dan Slameto (2010:180), minat belajar yaitu adanya kecenderungan, kegairahan, dorongan, keinginan, perasaan senang, dan tertarik terhadap kegiatan pembelajaran. Kecenderungan, kegairahan, dorongan, keinginan, dan sebagainya akan terwujud dan teramati melalui tingkat laku yang berupa aktivitas belajar. Dengan demikian, minat belajar dapat diamati melalui aktivitas belajar yang berupa: 1) kegairahan (nampak melalui aktifitas membentuk kelompok dan mengikuti apersepsi), 2) Tertarik pada pelajaran (nampak melalui 
menyimak pembelajaran, menyimak ceramah, menulis pertanyaan dan mengikuti demonstrasi, 3) Mempunyai inisiatif untuk mau mengumpulkan jawaban dan bertanya jawab.

Pembelajaran S-ST dalam penelitian ini merupakan pembelajaran inovatif dalam kurikulum 2013 dan akan digunakan sebagai percobaan dan sebagai pembandingnya adalah pembelajaran konvensional. Pembelajaran konvensional menurut Widiantari (2012:24), Yeni (2011: Santyasa dalam Widiantari (2012), dan Djamarah (2010 : 97) yaitu pembelajaran yang biasa dilaksanakan dikelas. Guru cenderung aktif menjelaskan dengan metode ceramah. Siswa menerima informasi dan siswa diminta untuk mendemonstrasikan materi yang dipelajari. Untuk melaksanakan pembelajaran konvensional terdapat 4 (empat) langkah, menurut Syahrul (2013:37) dan Priska Timbangalan (2015 : 6) yang meliputi: 1) Memberikan apersepsi, 2) Menyimak materi, 3) Mengikuti demonstrasi, 4)Bertanya jawab.

Desain pembelajaran S-ST untuk Tema 8 Lingkungan Sahabat Kita, Subtema 2 Perubahan Lingkungan Pembelajaran 2. Dalam pembelajaran tematik ini terdiri dari 3 mata pelajaran yaitu Bahasa Indonesia dengan KD 3.8 Menguraikan urutan peristiwa atau tindakan yang terdapat pada teks nonfiksi dan KD 4.8 Menyajikan kembali peristiwa atau tindakan dengan memperhatikan latar cerita yang terdapat pada teks fiksi, mata pelajaran IPA dengan KD 3.8 Menganalisis siklus air dan dampaknya pada peristiwa di bumi serta kelangsungan makhluk hidup dan KD 4.8 Membuat karya tentang skema siklus air berdasarkan informasi dari berbagai sumber, dan mata pelajaran SBdP dengan KD 3.3 Memahami pola lantai dalam tari kreasi daerah dan KD 4.3 Mempraktikkan pola lantai pada gerak tari kreasi daerah; melalui langkah-langkah 1) Membentuk kelompok masing-masing 5 siswa, 2) Menyimak materi Siklus Air dan Dampak bagi Lingkungan, 3) Menulis pertanyaan tentang Siklus Air dan Dampaknya di kertas yang akan digulung seperti bola, kemudian dilempar ke salah satu teman, 4) Mengumpulkan jawaban dari teman secara lisan tentang Siklus Air dan Dampak bagi Lingkungan, 5) Membuat kesimpulan jawaban teman tentang Siklus Air dan Dampak bagi Lingkungan, 6) Mengkomunikasikan hasil temuan. 


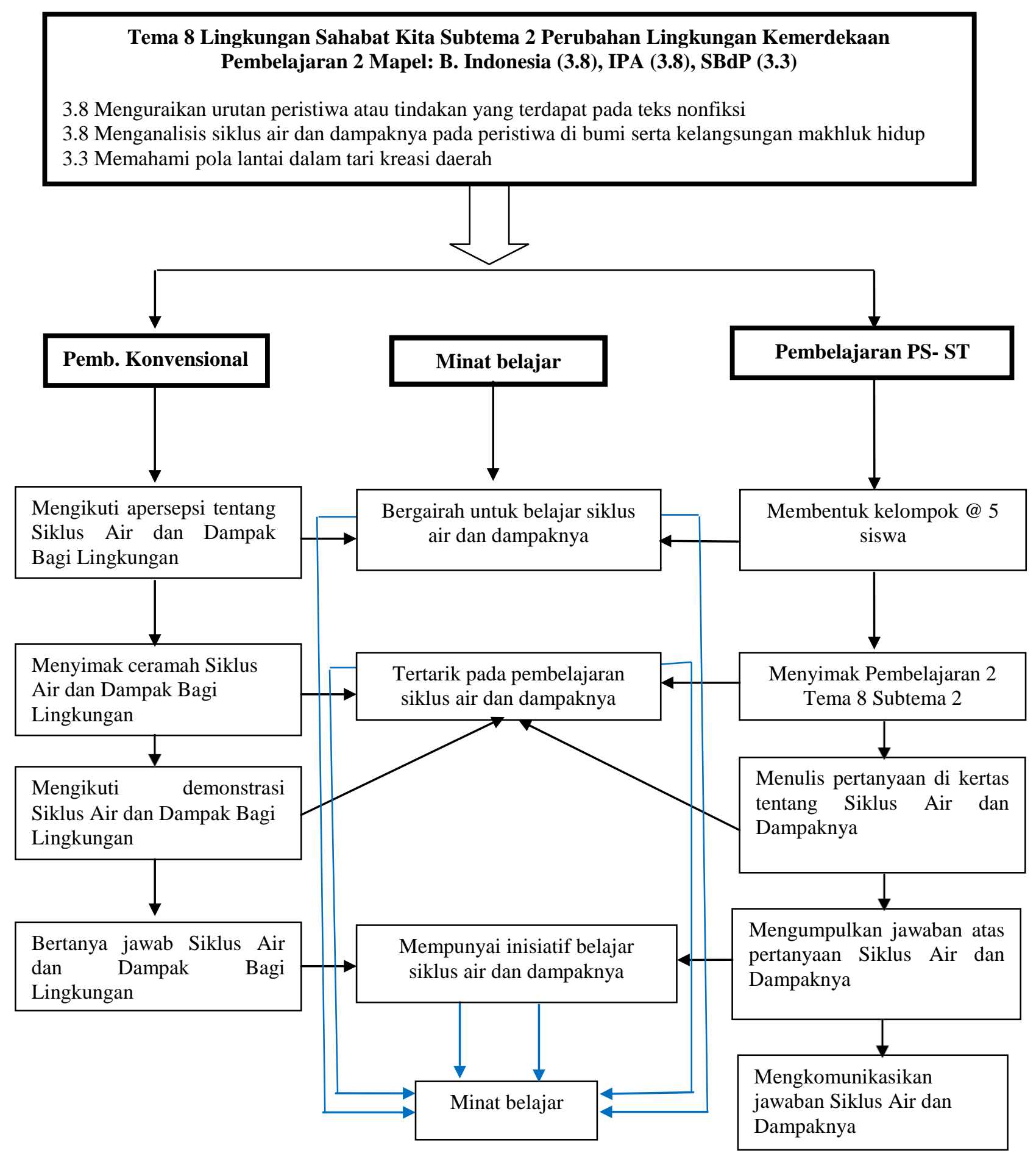

3.8 Menguraikan urutan peristiwa atau tindakan yang terdapat pada teks nonfiksi

3.8 Menganalisis siklus air dan dampaknya pada peristiwa di bumi serta kelangsungan makhluk hidup

3.3 Memahami pola lantai dalam tari kreasi daerah

\section{Gambar 1}

Kerangka Berpikir Pengaruh Pendekatan Scientific dan Model Snowball Throwing Terhadap Minat Belajar Siswa

Dalam pembelajaran S-ST ada beberapa aktifitas belajar yang nampak dari minat belajar siswa. Minat belajar adalah besarnya skor dari 1) Bergairah untuk belajar siklus air dan dampaknya (membentuk kelompok dan mengikuti apersepsi), 2) 
Tertarik pada pembelajaran siklus air dan dampaknya (menyimak, menulis, mengikuti demonstrasi), dan 3) Mempunyai inisiatif belajar siklus air dan dampaknya (mengumpulkan jawaban dan bertanya jawab).

Pembelajaran konvensional adalah pembelajaran yang menggunakan langkahlangkah: 1) Mengikuti apersepsi tentang siklus air dan dampak bagi lingkungan, 2) Menyimak ceramah siklus air dan dampak bagi lingkungan , 3) Mengikuti latihan mendemonstrasikan siklus air dan dampak bagi lingkungan, 4) Mengecek pemahaman siklus air dan dampak bagi lingkungan secara lesan.

Penjelasan pengaruh pembelajaran S-ST terhadap minat belajar siswa kelas 5 tersebut di atas dapat dibuat secara rinci, seperti disajikan melalui Gambar 1.

\section{METODOLOGI}

Jenis penelitian ini adalah penelitian eksperimen dengan menggunakan desain nonequivalent control group design. Teknik pengambilan sampel adalah purposive stratified quota sampling artinya pengambilan sample dengan menentukan tujuan terlebih dahulu, yaitu siswa yang berminat belajar, kemudian menentukan strata/ kelas V dan menentukan quota/ jumlah lebih dari 25 siswa per kelas. Penelitian eksperimen ini akan menyelidiki hubungan sebab dan akibat antara kelas eksperimen yang diberi perlakuan dan kelas kontrol yang tanpa perlakuan. Desain eksperimen penelitian secara rinci disajikan dalam Tabel 1.

Tabel 1. Desain Eksperimen

\begin{tabular}{lll}
\hline $\mathbf{O}_{1}$ & $\underline{\mathbf{X}}$ & $\underline{\mathbf{O}}_{2}$ \\
\hline$\underline{\mathbf{O}}_{3}$ &
\end{tabular}

Keterangan:

X : Perlakuan menggunakan MP S-ST

$\mathbf{O}_{1} \quad$ : Pengukuran pretest kelompok eksperimen

$\mathbf{O}_{2} \quad$ : Pengukuran posttest kelompok eksperimen

$\mathbf{O}_{3} \quad$ : Pengukuran pretest kelompok kontrol

O4 : Pengukuran posttest kelompok kontrol

Penelitian ini dilakukan di SD Negeri Ledok 01 Salatiga yang terletak di Jalan Argotunggal No. 3 Argomulyo, Kota Salatiga. Variabel penelitian ini adalah pendekatan scientific dan model snowball throwing sebagai variabel bebas, sedangkan variabel terikat adalah minat belajar siswa.

Teknik analisis data menggunakan uji t dengan syarat terdapat homogenitas dan normalitas data. Untuk memenuhi persyaratan homogenitas dan normalitas, 
terlebih dahulu instrumen penelitian dilakukan validitas. Validitas mempunyai arti sejauh mana ketepatan dan kecermatan suatu alat ukur dalam melakukan fungsi ukurannya (Azwar 1986). Selain itu validitas adalah suatu ukuran yang menunjukkan bahwa variabel yang diukur memang benar-benar variabel yang hendak diteliti oleh peneliti (Cooper dan Schindler, dalam Zulganef, 2006). Hasil uji validitas instrumen penelitian secara rinci disajikan melalui Tabel 2.

\section{Tabel 2 Hasil Uji Validitas}

\begin{tabular}{|c|c|c|c|c|}
\hline & $\begin{array}{c}\text { Item-Total Statistics } \\
\text { Scale Mean if } \\
\text { Item Deleted }\end{array}$ & $\begin{array}{c}\text { Scale Variance } \\
\text { if Item Deleted }\end{array}$ & $\begin{array}{c}\text { Corrected Item- } \\
\text { Total Correlation }\end{array}$ & $\begin{array}{c}\text { Cronbach's } \\
\text { Alpha if Item } \\
\text { Deleted }\end{array}$ \\
\hline S1 & 13,52 & 56,973 &, 795 &, 933 \\
S2 & 13,55 & 59,470 &, 450 &, 937 \\
S3 & 13,52 & 61,973 &, 129 &, 941 \\
S4 & 13,52 & 57,116 &, 775 &, 933 \\
S5 & 13,59 & 57,751 &, 677 &, 934 \\
S6 & 13,55 & 59,470 &, 450 &, 937 \\
S7 & 13,69 & 62,007 &, 124 &, 942 \\
S8 & 13,48 & 56,973 &, 808 &, 932 \\
S9 & 13,48 & 56,973 &, 808 &, 932 \\
S10 & 13,59 & 57,751 &, 677 &, 934 \\
S11 & 13,52 & 57,116 &, 775 &, 933 \\
S12 & 13,48 & 62,473 &, 067 &, 942 \\
S13 & 13,59 & 57,751 &, 677 &, 934 \\
S14 & 13,52 & 56,973 &, 795 &, 933 \\
S15 & 13,48 & 56,973 &, 808 &, 932 \\
S16 & 13,52 & 56,973 &, 795 &, 933 \\
S17 & 13,55 & 60,756 &, 282 &, 940 \\
S18 & 13,52 & 57,116 &, 775 &, 933 \\
S19 & 13,59 & 57,751 &, 677 &, 934 \\
S20 & 13,48 & 56,973 &, 808 &, 932 \\
S21 & 13,52 & 56,973 &, 795 &, 933 \\
S22 & 13,59 & 59,537 &, 439 &, 937 \\
S23 & 13,59 & 57,751 &, 677 &, 934 \\
S24 & 13,55 & 62,256 &, 091 &, 942 \\
S25 & 13,52 & 56,973 &, 795 &, 933 \\
\hline r tabel = 0.367 & & & & \\
\hline
\end{tabular}

Berdasarkan tabel di atas, nilai korelasi $r \geq 0,367$ adalah butir soal yang valid yakni soal nomor $1,2,4,5,6,8,9,10,11,13,14,15,16,18,19,20,21,22,23$, dan 25. Soal nomor $3,7,12,17$, dan 24 , nilai $r$ hitung lebih kecil dari 0,367 , maka butir soal tersebut tidak valid.

Uji normalitas digunakan untuk mengetahui apakah data pretest kelas eksperimen dan kelas kontrol berdistribusi normal atau tidak. Hasil uji normalitas instrumen pretest kelas eksperimen dan kelas kontrol disajikan dalam Tabel 3. 
Tabel 3 Uji Normalitas

\begin{tabular}{|l|r|r|r|}
\hline \multirow{2}{*}{} & \multicolumn{3}{|c|}{ Shapiro-Wilk } \\
\cline { 2 - 4 } & Statistic & \multicolumn{1}{c|}{ df } & \multicolumn{1}{c|}{ Sig. } \\
\hline Kelas Eksperimen & .947 & 29 & .155 \\
Kelas Kontrol & .936 & 29 & .081 \\
\hline
\end{tabular}

*. This is a lower bound of the true significance.

a. Lilliefors Significance Correction

Berdasarkan tabel 3, hasil uji normalitas kelas eksperimen, signifikansi sebesar 0,155 lebih besar dari $0,05(0,155>0,05)$, hasil uji normalitas kelas kontrol diperoleh signifikansi sebesar 0,081 atau lebih besar dari 0,05 (0,081 > 0,05), maka berdasarkan hasil pretest, kelas eksperimen dan kelas kontrol berdistribusi normal. Hasil uji homogenitas kelas eksperimen dan kelas kontrol disajikan dalam Tabel 4.

Tabel 4. Uji Homogenitas

Hasil Belajar

\begin{tabular}{|c|c|c|c|}
\hline Levene Statistic & $\mathrm{df1}$ & $\mathrm{df} 2$ & sig. \\
\hline .059 & 1 & 56 & .809 \\
\hline
\end{tabular}

Berdasarkan tabel 4, hasil uji homogenitas instrumen pretest kelas eksperimen dan kelas kontrol diperoleh nilai signifikansi sebesar 0,809 atau lebih besar dari 0,05 $(0,809>0,05)$, maka kelas eksperimen dan kelas kontrol memiliki varian yang sama atau homogen.

\section{HASIL PENELITIAN DAN PEMBAHASAN}

Pembelajaran S-ST dengan Tema 8 Subtema 2 Pembelajaran 2 dilaksanakan pada kelas eksperimen (kelas yang diberi perlakuan pembelajaran S-ST), dan pembelajaran kelas kontrol (kelas tanpa ada perlakuan pembelajaran S-ST). Pembelajaran di kelas eksperimen dilakukan dengan langkah membentuk kelompok @ 5 siswa, menyimak pembelajaran siklus air dan dampaknya, menulis pertanyaan di kertas tentang siklus air dan dampaknya, mengumpulkan jawaban atas pertanyaan siklus air dan dampaknya, mengkomunikasikan jawaban siklus air dan dampaknya. Pelaksanaan pembelajaran di kelas eksperimen berjalan lancar dan seluruh siswa mengikuti semua aktivitas pembelajaran.

Pelaksanaan pembelajaran di kelas kontrol, adalah mengikuti apersepsi tentang siklus air dan dampak bagi lingkungan, menyimak ceramah siklus air dan dampak bagi lingkungan, mengikuti demonstrasi siklus air dan dampak bagi lingkungan, bertanya jawab siklus air dan dampak bagi lingkungan. Dalam 
pembelajaran, seluruh siswa mengikuti semua kegiatan. Dengan demikian, pembelajaran di kelas kontrol berjalan lancar.

Pengukuran minat belajar untuk kelas eksperimen dilaksanakan ketika siswa membentuk kelompok, siswa menyimak pembelajaran siklus air, siswa menulis pertanyaan dan siswa mengumpulkan jawaban atas pertanyaan. Siswa mau membentuk kelompok adalah menunjukkan kegairahannya dalam belajar. Siswa menyimak pembelajaran siklus air, menunjukkan ketertarikan siswa untuk belajar. Siswa menulis pertanyaan di kertas, menunjukkan ketertarikan untuk belajar. Siswa mengumpulkan jawaban atas pertanyaan, menunjukkan inisiatif untuk dapat menjawab pertanyaan.

Pengukuran minat belajar untuk kelas kontrol dilaksanakan ketika siswa mengikuti apersepsi pembelajaran awal, menyimak ceramah guru, mengikuti demonstrasi dan tanya jawab. Siswa mengikuti apersepsi pembelajaran awal menunjukkan kegairahannya untuk belajar diawali dengan kegiatan apersepsi yang diberikan. Siswa menyimak ceramah guru, menunjukkan ketertarikan siswa untuk belajar dengan memperhatikan penjelasan gurfu. Siswa mengikuti demonstrasi menunjukkan ketertarikan siswa untuk memperhatikan materi. Siswa melakukan tanya jawab, menunjukkan inisiatif siswa dalam bertanya dan menjawab.

Teknik analisis data yang dilakukan menggunakan teknik uji t (independent sample t-test). Pengambilan keputusan adalah 1) Jika signifikansi (2-tailed) $<0,05$, maka Ho ditolak dan Ha diterima, 2) Jika signifikansi (2-tailed) > 0,05, maka Ho diterima dan Ha ditolak. Hasil independent sample t-test, secara rinci disajikan dalam Tabel 5.

Tabel 5

Independent Samples Test

\begin{tabular}{|c|c|c|c|c|c|c|c|c|c|c|}
\hline & \multicolumn{2}{|c|}{$\begin{array}{l}\text { Levene's Test } \\
\text { for } \\
\text { Equality } \\
\text { of } \\
\text { Varianc } \\
\text { es } \\
\end{array}$} & \multicolumn{7}{|c|}{ t-test for Equality of Means } \\
\hline & & \multirow[t]{2}{*}{$F$} & \multirow[t]{2}{*}{ Sig. } & \multirow[t]{2}{*}{$t$} & \multirow[t]{2}{*}{$\mathrm{df}$} & \multirow[t]{2}{*}{$\begin{array}{l}\text { Sig. } \\
(2- \\
\text { tailed })\end{array}$} & \multirow[t]{2}{*}{$\begin{array}{l}\text { Mean } \\
\text { Differ } \\
\text { en ce }\end{array}$} & \multirow[t]{2}{*}{$\begin{array}{l}\text { Std. } \\
\text { Error } \\
\text { Differ } \\
\text { en ce }\end{array}$} & \multicolumn{2}{|c|}{$\begin{array}{c}95 \% \\
\text { Confidence } \\
\text { Interval of the } \\
\text { Difference }\end{array}$} \\
\hline & & & & & & & & & Lower & Upper \\
\hline $\begin{array}{l}\text { Minat } \\
\text { Belaj } \\
\text { ar }\end{array}$ & $\begin{array}{l}\text { Equal } \\
\text { variances } \\
\text { assumed } \\
\text { Equal } \\
\text { variances } \\
\text { not assumed }\end{array}$ & $\begin{array}{l}1.30 \\
9\end{array}$ & $\begin{array}{l}.25 \\
7\end{array}$ & $\begin{array}{r}2.24 \\
1 \\
\\
2.24 \\
1\end{array}$ & $\begin{array}{c}56 \\
\\
53 . \\
8 \\
85\end{array}$ & .029 & $\begin{array}{l}2.621 \\
2.621\end{array}$ & $\begin{array}{l}1.169 \\
1.169\end{array}$ & .276 & 4.965 \\
\hline
\end{tabular}


Setyaningrum, Wardani, dan Prasetyo: Pengaruh Pembelajaran Scientific...

Berdasarkan tabel 5 independent sample t-test, nilai t sebesar 2,241 >2,009 $(\mathrm{t}$ tabel), maka Ho ditolak dan Ha diterima. Dengan kriteria hipotesis sebagai berikut:

$\mathrm{H}_{\mathrm{o}}$ : Terdapat perbedaan rata-rata minat belajar siswa antara pembelajaran S-ST dan pembelajaran konvensional

$\mathrm{H}_{\mathrm{a}}$ : Tidak terdapat perbedaan rata-rata minat belajar siswa antara pembelajaran S-ST dan pembelajaran konvensional

Perbedaan rata-rata skor minat belajar kelas eksperimen dan kelas kontrol disajikan dalam tabel 6 sebagai berikut.

Tabel 6. Group Statistic Minat Belajar Kelas Eksperimen dan Kelas Kontrol

\begin{tabular}{|l|l|r|r|r|r|}
\hline & Kelas & N & \multicolumn{1}{c|}{ Mean } & Std. Deviation & Std. Error Mean \\
\hline Minat & Kelas Eksperimen & 29 & 47.59 & 3.987 & .740 \\
Belajar & Kelas Kontrol & 29 & 44.97 & 4.873 & .905 \\
\hline
\end{tabular}

Berdasarkan Tabel 6 di atas, diketahui jumlah siswa minat belajar untuk kelas eksperimen dan kelas kontrol masing-masing kelas sebanyak 29 siswa. Skor rata-rata minat belajar kelas eksperimen sebesar 47,59, dan skor rata-rata minat belajar kelas kontrol sebesar 44,97. Perbedaan rata-rata skor minat belajar antara kelas eksperimen dan kelas kontrol adalah 2,62. Besarnya perbedaan skor rata-rata minat belajar, juga ditunjukkan oleh tabel 5 mean difference 2,621. Dengan demikian, terdapat perbedaan rata-rata minat belajar antara kelas eksperimen dan kelas kontrol. Perbedaan rata-rata minat belajar yang signifikan (nyata) antara kelas eksperimen dan kelas kontrol ditunjukkan oleh nilai signifikansi (2-tailed) $0,029<0,05$, maka Ho ditolak dan Ha diterima. Artinya Terdapat perbedaan pembelajaran S-ST dan pembelajaran konvensional terhadap minat belajar siswa kelas 5 Tema 8 Subtema 2 Pembelajaran 2. Klasifikasi skor minat belajar kelas eksperimen dan kelas kontrol disajikan dalam tabel 7 sebagai berikut.

Tabel 7. Klasifikasi Minat Belajar

\begin{tabular}{|c|l|c|c|c|c|}
\hline \multirow{2}{*}{ Interval Skor } & \multirow{2}{*}{ Klasifikasi Minat } & \multicolumn{2}{|c|}{ Kelas Eksperimen } & \multicolumn{2}{c|}{ Kelas Kontrol } \\
\cline { 3 - 6 } & & Frekuensi & $\begin{array}{c}\text { Persentase } \\
(\boldsymbol{\%})\end{array}$ & Frekuensi & $\begin{array}{c}\text { Persentase } \\
(\boldsymbol{\%})\end{array}$ \\
\hline $49-60$ & Sangat Berminat & 25 & 86,20 & 23 & 79,31 \\
\hline $37-48$ & Berminat & 4 & 13,8 & 6 & 20,63 \\
\hline \multicolumn{2}{|r}{ Jumlah } & 29 & 100 & 29 & 100 \\
\hline
\end{tabular}

Berdasarkan tabel 7, siswa yang sangat berminat belajar di kelas eksperimen sebanyak 
Setyaningrum, Wardani, dan Prasetyo: Pengaruh Pembelajaran Scientific...

25 siswa $(86,20 \%$ dari seluruh siswa) dan di kelas kontrol sebanyak 23 siswa $(79,31 \%$ dari seluruh siswa). Siswa yang berminat belajar di kelas eksperimen sebanyak 4siswa (13,8\% dari seluruh siswa) dan di kelas kontrol sebanyak 6 siswa (20,63\% dari seluruh siswa). Terdapat perbedaan persentase sebesar 6,89\% dari seluruh siswa ( 2 siswa) pencapaian klasifikasi sangat berminat di kelas eksperimen daripada kelas kontrol. Kelas eksperimen mencapai jumlah siswa yang sangat berminat belajar lebih banyak daripada kelas kontrol. Namun pencapaian siswa yang berminat belajar, kelas kontrol lebih tinggi daripada kelas eksperimen.

Hasil penelitian yang sejenis dan mendukung hasil penelitian ini, dilakukan oleh Kusumawati (2017) dengan judul penelitian Pengaruh Model Snowball Throwing Terhadap Minat Belajar Siswa. Temuan dari hasil penelitiannya adalah penerapan model pembelajaran snowball throwing dapat mempengaruhi minat belajar siswa kelas V SDN Bondrang Kabupaten Ponorogo. Hasil rata-rata minat belajar kelas eksperimen adalah 83,23 dan kelas kontrol adalah 71,47. Jadi ada perbedaan rata-rata minat belajar antara kelas eksperimen dan kelas kontrol sebesar 11,76. Hasil penelitian Kusumawati, juga dihasilkan dalam penelitian ini bahwa terdapat perbedaan rata-rata minat belajar antara kelas pembelajaran S-ST dan kelas pembelajaran konvensional sebesar 2,621. Penelitian lain yang sejalan, dilakukan oleh I Kt Sandi, pada tahun 2014 menemukan signifikansi minat belajar siswa pada kelas kontrol sebesar 0,067>0,05 dan signifikansi minat belajar siswa pada kelas eksperimen sebesar 0,129>0,05 kategori sangat berminat. Begitu juga dalam penelitian ini, memperoleh signifikansi minat belajar sebesar 0,029<0,05. Maka Ho ditolak.

Penelitian lain yang sejalan dilakukan oleh Abdul Rahman pada tahun 2013. Hasil penelitian menunjukkan terdapat perbedaan minat belajar siswa antara pembelajaran snowball throwing dan pembelajaran non snowball throwing dengan signifikansi 2-tailed 0,029<0,05. Maka Ho ditolak, artinya bahwa terdapat perbedaan minat belajar siswa antara kelas ekperimen dan kelas kontrol.

Hasil analisis skor rata-rata minat belajar siswa kelas eksperimen dengan pemberian perlakuan S-ST dan skor rata-rata minat belajar siswa kelas kontrol dengan tidak ada pemberian perlakuan menunjukkan, perbedaan skor rata-rata minat belajar kelas eksperimen lebih tinggi dibandingkan dengan skor rata-rata minat belajar kelas kontrol. Maka dari itu terdapat pengaruh pembelajaran S-ST terhadap minat belajar siswa. 
Pendekatan yang didasarkan pada prinsip bahwa cara belajar terbaik bagi peserta didik adalah dengan melakukan, dengan menggunakan semua inderanya, dan dengan mengeksplorasi lingkungannya yang terdiri atas orang, hal, tempat dan kejadian yang terjadi dalam kehidupan sehari-hari peserta didik (pembelajaran kontekstual). (Wardani Naniek Sulistya:2012)

\section{KESIMPULAN DAN SARAN}

Hasil penelitian menunjukkan nilai signifikansi (2-tailed) 0,029<0,05, maka: Ho ditolak artinya terdapat perbedaan pembelajaran S-ST dan pembelajaran konvensional terhadap minat belajar siswa kelas 5 Tema 8 Subtema 2 Pembelajaran 2, dan Ha diterima artinya terdapat perbedaan pembelajaran S-ST dan pembelajaran konvensional terhadap minat belajar siswa kelas 5 Tema 8 Subtema 2 Pembelajaran 2. Hasil penelitian juga menunjukkan $t$ hitung sebesar 2,241 > 2,009 ( $\mathrm{t}$ tabel), maka Ho ditolak dan $\mathrm{Ha}$ diterima. Artinya $\mathrm{H}_{\mathrm{o}}$ Terdapat perbedaan rata-rata minat belajar siswa antara pembelajaran S-ST dan pembelajaran konvensional; $\mathrm{H}_{\mathrm{a}}$ Tidak terdapat perbedaan rata-rata minat belajar siswa antara pembelajaran S-ST dan pembelajaran konvensional. Saran yang dapat diberikan untuk peningkatan kualitas pembelajaran adalah, diharapkan guru berkomitmen melaksanakan pembelajaran S-ST agar siswa sangat berminat dalam belajar.

\section{REFERENSI}

Asmani, Jamal Ma'mur. 2011. 7 Tips Aplikasi PAKEM (Pembelajaran Aktif, Kreatif, Efektif, dan Menyenangkan). Jogjakarta: DIVA Press.

Dewi, M. P., Putra, I. K. A., \& Negara, I. G. A. O. (2013). Pengaruh Model Pembelajaran Snowball Throwing terhadap Hasil Belajar IPA Siswa Kelas V SD di Gugus Sri Kandi Kecamatan Denpasar Timur. MIMBAR PGSD Undiksha.

Djamarah, Syaiful Bahri dan Aswan Zain. 2010. Strategi Belajar Mengajar. Jakarta: Rineka Cipta

Ernawati, N. K. T., Murda, I. N., \& Rati, N. W. (2016). Penerapan Model Pembelajran Snowball Throwing Untuk Meningkatkan Motivasi Dan Hasil Belajar IPA Siswa Kelas III Semester Genap SDN 1 Tegal Badeng Timur Kecamatan Negara Kabupaten Jembrana Tahun Pelajaran 2015/2016. Mimbar PGSD Undiksha.

Hosnan. 2014. Pendekatan Saintifik dan Kontekstual dalam Pembelajaran Abad 21. Bogor: Ghalia Indonesia. 
Ismail, Arif. 2008. Model-Model Pembelajaran Mutakhir. Yogyakarta: Pustaka Pelajar

Kusumawati, N. (2017). Pengaruh Model Pembelajaran Kooperatif dengan Snowball Throwing Terhadap Hasil Belajar IPA Pada Siswa Kelas IV SDN Bondrang Kecamatan Sawoo Kabupaten Ponorogo. Ibriez: Jurnal Kependidikan Dasar Islam Berbasis Sains, 2(1), 1-12.

Linovia, D. A. (2015). Penerapan Model Pembelajaran Snowball Throwing Untuk Meningkatkan Hasil Belajar Matematika Materi Bilangan Romawi Pada Siswa Kelas IV MI Mafatihul Ulum Balesono Ngunut Tulungagung. Skripsi.

Mulyasa, E. (2012). Manajemen Pendidikan Karakter. Jakarta: PT Bumi Aksara

Saminanto. 2010. Ayo Praktik PTK (Penelitian Tindakan Kelas). Semarang: Rasail Media Grup.

Sandi, I. K., Suwatra, I. I. W., \& Widiana, I. W. (2014). Pengaruh Model Pembelajaran Snowball Throwing Terhadap Hasil Belajar IPA Dengan Kovariabel Kemampuan Berpikir Kreatif Siswa Kelas IV SD. Mimbar PGSD Undiksha, 2(1).

Siregar, E, hartini, N. 2014. Teori Belajar dan Pembelajaran. Bogor: Penerbit Ghalia Indonesia

Slameto. (2010). Belajar dan Faktor-Faktor yang Mempengaruhinya. Jakarta : PT. Rineka Cipta.

Suprijono. 2011. Cooperative Lerning Teori dan Aplikasi Paikem. Surabaya: Pustaka Belajar

Wardani Naniek Sulistya. 2012. Efektifitas Model Perkuliahan (Asesmen Pembelajaran) Kooperatif Tipe Investigasi Kelompok (IK) Untuk Meningkatkan Kreativitas Mahasiswa S1 PGSD FKIP. Prosiding Seminar Lembaga Pengembangan Pendidikan Universitas Sebelas Maret

Widiantari. 2012. Model Pembelajaran Konvensional. Bandung: Pustaka Setia

Wijayanti, A. (2014). Pengembangan Autentic Assesment Berbasis Proyek Dengan Pendekatan Saintifik Untuk Meningkatkan Keterampilan Berpikir Ilmiah Mahasiswa. Jurnal Pendidikan IPA Indonesia, 3(2). 